\title{
Impact of Workplace Spirituality on Employee Productivity in Nepalese Hospitality Organizations
}

\author{
Gangaram Biswakarma \\ Central Department of Management, Tribhuvan University, Kathmandu \\ drgrbiswa@gmail.com
}

\begin{abstract}
In a rapidly changing and competitive world, managing an organization is becoming very complex. It is utmost vital to gain a competitive advantage by an organisation to survive the cut-throat competition. Hospitality organizations is one of them. Uniquely, these organizations can strengthen and improve its human resource productivity to gain competitive advantage. One of the element that influence productivity of employee is, how they are guided, mentored and supported in the organization and provided with workplace spirituality to contribute more effective in the organizational work process. Therefore, this research study aimed at analyzing the relationship between creating workplace spirituality, and how it influences the employee productivity in Nepalese hospitality organization. A sample of 150 employees from hospitality organizations was selected for the study with convenience sampling method. The study concluded that there is a positive relationship between workplace spirituality and productivity and workplace spirituality positively predict employee productivity in hospitality organization. This suggests that the workplace spirituality plays an important role to make the employee productive and satisfied. Employee thus become more productive over the long run compared with employees in organizations where spirituality is ignored or disrespected. Therefore, hospitality organizations should emphasize to make their respective organization spiritual and adopt spiritual environment, and also emphasize spiritual leadership.
\end{abstract}

Keywords: Workplace spirituality, productivity, spirituality, spiritual leadership. 


\section{Background}

The hospitality sector has been emerging as greater importance by the day in the country. It becomes more prominent in the context of Nepal, according to World Travel \& Tourism Council (WTTC) report 2017, the hospitality industry along with the tourism industry go hand in hand and contribute about the direct contribution of Travel \& Tourism to GDP was USD 2,306.0bn (3.1\% of total GDP) in 2016, and is forecast to rise by $4.0 \%$ pa, from $2017-2027$, to USD $3,537.1$ bn (3.5\% of total GDP) in 2027. However, hospitality sector growth cannot be sustained for long unless it is linked with the highest productivity of this sector. In a rapidly changing and competitive world, managing an organization is becoming very complex. It is utmost vital to gain a competitive advantage by an organisation to survive the cut-throat competition. Uniquely, the organization can strengthen and improve its human resource productivity, efficiency and effectiveness. Consequently, in an organization employee productivity is utmost desired to achieved the organizational goals and its objectives. One of the element that influence productivity of employee is, how they are guided, mentored and supported in the organization. It is the leadership function comes as one of the critical element within the domain of human resource productivity. Moreover, spirituality in leadership can further strengthen the influence in higher levels of employee productivity. Likewise, workplace spirituality focus towards creating values, attitudes, and behaviors that are essential to internally motivate individuals in an organization. In consequence, they create a sense of mystical of well-being and survival, and nourish the inner life of followers to make their life meaningful, work meaningful, being in a community sense, and aligning themselves to the organizational goals. Therefore, workplace spirituality can undoubtedly develop employees' contribution more effective in the organizational work process.

In like manner, sustainability of hospitality organisation depends on quality of service they provide to the customers. In hospitality organization, employees interact directly to the customers, and their behaviour with the customer determine the overall performance of the organisation. In hospitality service scenario, customer satisfaction mainly depends on the process of service delivery, that is highlighted by the efforts of the employees. When employees feel a sense of support, well-being, feels work as meaningful, with community sense, and aligning themselves to the organizational goals, they can feed their utmost effort/ productivity for the customer satisfaction and overall accomplishment of organizational goals.

The present status of the spirituality in workplace and work-related variables like productivity is left unattended in this sector, which can be considered for contribution towards growth and sustainability of this sector. This is little curiosity concerning the impact of workplace spirituality on employee productivity in present time to this sector. 
At the present time, the understanding of spirituality is only concerned with religion. However, 'Spirituality' in the context of organization is not religion. The spirituality does differ from religion in organizational context. Moreover, it is altogether about well-being, creating values, attitudes, and behaviors that are essential to internally motivate leaders as well as the followers and other. Spirituality grounds people in their work and allows them to connect with the transcendent in all they do. Research in the areas of workplace spirituality and spirituality and performance is still in its infancy, as indicated by typical characteristics of paradigm development such as a lack of common understanding of the concept and unclear boundaries between workplace spirituality and leadership (Dent, Higgins, \& Wharff, 2005). Therefore, how spirituality impacts the organizations and individuals; such as leaders and followers (employees) are the main areas of empirical research, which tend to highlight the importance of spirituality in the workplace (Mohd Yusof and Mahadzirah, 2014). Likewise, in Nepal the understanding of workplace spirituality and productivity is still unexplored, and if understood, leaders in present time can adopt the spirituality in their leadership to make their organisation in workplace spirituality and productivity of employee, so that the organizational can achieved its objectives and goals.

Therefore, this research study aimed at analyzing the relationship between creating workplace spirituality, and how it influences the employee productivity in Nepalese hospitality organization.

\section{Research objectives}

The main purpose of this research is to analyze the impact of workplace spirituality and employee productivity in hospitality organization in Nepal. The following research objectives are formulated to guide this research:

Objective 1 : To examine the level of workplace spirituality in Nepalese hospitality organizations.

Objective 2 : To analyze the impact of workplace spirituality on productivity in Nepalese hospitality organizations.

\section{Literature review}

Workplace spirituality: Workplace spirituality is a state or experience that can provide individuals with direction or meaning, or provide feelings of understanding, support, inner wholeness or connectedness (Smith and Rayment, 2007). According to Ashmos and Duchon (2000), it is the conditions for community, meaning at work, inner life, blocks to Spirituality, personal responsibility, positive connection with other individuals, contemplation, work unit community, positive work unit values, organizational values, individual and organisation. It is a recognition that 
employees have an inner life which nourishes and is nourished by meaningful work, taking place in the context of a community (Ashmos and Duchon, 2000). Mitroff and Denton (1999) indicates that employees of spiritual organizations have basic beliefs and values in the workplace.

Meaningful work, sense of community, alignment between organizational and individual values, sense of contribution to the community, and inner life are five dimensions of the workplace spirituality. Meaningful work refers to sense of enjoyment of work, comprises items related to the sense of joy and pleasure at work (Milliman et al., 2003), (Ashmos and Duchon, 2000). Sense of community refers to team spirit, mutual care between members, sense of community and sense of common purpose (Milliman et al. 2003). Alignment between organizational and individual values, refers to the congruence between organizational values and the individual value and inner life of individuals (Milliman et al., 2003; Ashmos and Duchon, 2000). Sense of contribution to the community refers to aggregates items meaning that work done by the individual is congruent with his/her personal life values and is helpful for the community (Rego Cunha, 2008). Likewise, opportunities for inner life, includes descriptors concerning the way the organization respects the spirituality and spiritual values of the individual (Ashmos and Duchon, 2000).

Productivity: Employees who have hope/faith in the organization's vision and who experience calling and membership will "Do what it takes" in pursuit of the vision to continuously improve and be more productive (Fry 2003). According to Nyhan (2000), productivity is the efficient production of results, benefits, or profits. The employees who experience calling and membership will do the right thing to achieve the organization's vision and to continuously improve and be more productive (Fry, 2003).

Relationship of workplace spirituality and productive: There are numerous studies that show the relationship between the spiritual leadership, workplace spirituality and productivity. According to Fry (2003), Fry et. al., (2005), Malone and Fry (2003), workplace spirituality lead to positive individual performance and also results in positive human health and psychological wellbeing, productivity. Reave (2005), also found the positive impact of spiritual values and practices to leadership effectiveness and subsequently to employee commitment, productivity, and customer satisfaction etc. Likewise, Garcia-Zamor (2003), Fairholm (1998), Fry (2003), Fry et al. (2005), Giacalone and Jurkiewicz (2003) and Millman et al. (2003), also found that spirituality is associated with the positive work related attitudes, including productivity. Likewise, spiritual leadership fosters spiritual well-being, which then positively influences employeelife satisfaction, corporate responsibility, organizational commitment and productivity, and financial performance (Fry \& Slocum, 2008). 
In a regional context, Bodla \& Ali (2012) studied banking sector in Pakistan, founds leadership spirituality influence individual outcomes like performance, organisation commitment and job satisfaction. In similar manner, Fry et. al. (2005) found spiritual leadership influence productivity. Zanganeh and Malekmohammadi (2015), Salehzadeh, Pool, Lashaki, Dolati \& Jamkhaneh (2015) found that a significant relationship between the spiritual leadership of organizational learning and empowerment. Rego et al. (2007), Tevichapong (2009), Tevichapong et al. (2010), Amabile and Kramer (2011), found a significant relationship between workplace spirituality and self-reported individual performance.

Research gap: The relationship between spirituality and work-related variables has been the subject of a limited number of empirical studies (Duffy 2006). Most of the research in terms of Spiritual Leadership Theory, Workplace spirituality are undertaken in western countries. Research in the areas of workplace spirituality and spirituality and leadership is still in its infancy, as indicated by typical characteristics of paradigm development such as a lack of common understanding of the concept and unclear boundaries between workplace spirituality and leadership (Dent, Higgins, \& Wharff, 2005). As such, there are few studies in Asian context, like in India and Iran. However, there is no research in Nepal regarding the spiritual leadership theory, workplace spirituality and its influence to the workplace employee attitudes. Moreover, the researches that has been undertaken in the context of the spiritual leadership, workplace spirituality globally. There are few researches that exist in explanation to the flow of spirituality at workplace spirituality and its impact on employee productivity.

In terms of the methodology, maximum of the researches in the arena of spiritual leadership Theory and workplace spirituality focuses and developed in an individualistic culture. Few researches in the context has been conducted in a collectivism culture. Therefore, having identified this gap in the extant literature, the present study that along with these linkages, will investigates the relationship and impact of workplace spirituality and productivity. It is a valuable attempt to plug the gap of knowledge in the context of Nepal. Moreover, in general sense people think spirituality is religion, however, in the context of organization is religion. The spirituality does differ from religion. This research also aims at putting the gap plugged in terms of, what is spirituality, and how does it differ from religion?

\section{Research framework and hypotheses}

Based on literature arguments, the hypotheses were advanced to identify the relationship of workplace spirituality and employee productivity.

$H_{1}$ : There is a positive impact of sense of meaningful work and employee productivity. 
$H_{2}$ : There is a positive impact of sense of community and employee productivity.

$H_{3}$ : There is a positive impact of alignment between organizational and individual values and employee productivity.

$H_{4}$ : There is a positive impact of sense of contribution to the community (organisation) and employee productivity.

$H_{5}$ : There is a positive impact of opportunities for the inner life and employee productivity.

\section{Research design, sampling and data collection procedure}

This study undertakes quantitative approach towards descriptive and explanatory research design. A descriptive research design was used for examining the current situation of workplace spirituality and self-perceived level of employee productivity. Similarly, the need of explanatory research design was employed to test the relationship and impact of exogenous variables over the endogenous variable in this study. A sample of 150 employees working in star category (three to five star) hotels and airline companies in Kathmandu was undertaken for the study. However, the researcher has received the data from 144 employees in hospitality sector and subsequently, data was analyzed. For the reliability of perception of the employee towards their respective organization, employee having at least six months of working experience considered as valid sample. The data was collected from these organizations with convenience sampling method.

\section{Conceptual model and instrumentation}

The conceptual framework for this study constituted of five construct of spirituality management and productivity. A structured survey questionnaire was utilized for collection of data. The key instrument was divided into two parts, one address the variables related to demographics information. The other part will be comprehensively deal the variable explain in conceptual framework. In the context of validity (convergent and discriminant validity), the questionnaire items developed by previous researcher was utilized. Workplace spirituality was measured by 18 items scale, based on Ashmos and Duchon (2000), Milliman et al., (2003) and Rego and Cunha (2008), representing five dimensions: Team's sense of community, Alignment between organizational and individual values, Sense of contribution to the community, Sense of enjoyment at work, and Opportunities for inner life. In similar manner, productivity was measured with 5 nos. items are developed and validated especially for Spiritual Leadership Theory research by Fry et. al., (2005) and Malone \& Fry (2003). The questionnaire items were developed in 6 point Likert scale. The reliability analysis shows 0.918 for 18 items of workplace spirituality, and 0.763 for 5 items of productivity. 


\section{Analytical strategy}

At first, based on data obtained, reliability was ascertained, next the descriptive analysis, correlation analysis and regression analysis has been performed to test the hypotheses. All tests were performed with SPSS v23.

\section{Results}

Research findings are presented in the following sections: (a) descriptive analysis, (b) correlation analysis (c) impact analysis, (d) hypotheses testing results.

\section{Demographic profile of respondents}

In this research, out of 144 respondents, the majority of respondents $79.2 \%$ were male and females constituted of $20.8 \%$. Majority of age group of below 30 years consists of $91.7 \%$, followed by $30-45$ years $(6.3 \%)$ and $45-60(2.1 \%)$. Likewise, the respondents' monthly income falls in wide categories of 10000-20000 (16.7\%), 2000030000 (14.6\%), 30000-40000 (8.3\%), 40000-50000 (25.0\%) and 50000+ (35.4\%). The experience of employee was found to be less than 2 years (47.9\%), 2-5 years $(31.3 \%)$, $5-10(10.4 \%), 10-15(2.1 \%)$, and $15+$ years $(8.3 \%)$. In similar manner, the positions of the respondents were assistant manager, cabin crew, CEO, Dy. manager, flight attendant, management trainee, marketing officer, commis chef and relationship manager etc.

\section{Status of workplace spirituality}

The result of descriptive statistics indicates that, there is a moderate level $(m=4.45$, $S D=0.749$, in 6 point Likert scale, with 6 being 'strongly agree') of the workplace spirituality in Nepalese hospitality organizations.

Table 1: Status of workplace spirituality and employee productivity

\begin{tabular}{|l|c|c|c|}
\hline Variables & Mean & Std. Deviation & Result \\
\hline Sense of meaningful work & 4.99 & 0.888 & Agree \\
\hline Sense of community/team & 4.80 & 0.867 & Agree \\
\hline $\begin{array}{l}\text { Alignment between organizational } \\
\text { and individual values }\end{array}$ & 4.45 & 0.909 & Slightly Agree \\
\hline $\begin{array}{l}\text { Sense of contribution to the } \\
\text { community (organisation) }\end{array}$ & 4.72 & 0.944 & Agree \\
\hline Opportunities for the inner life & 3.85 & $\mathbf{1 . 4 3 3}$ & Slightly Disagree \\
\hline Workplace Spirituality & $\mathbf{4 . 4 5}$ & $\mathbf{0 . 7 4 9}$ & Slightly Agree \\
\hline
\end{tabular}

Sense of meaningful work, has the highest mean value of $4.99(S D=0.888)$, within the dimensions of the workplace spirituality. It indicates that the respondents agreed 
on meaningfulness of their work, they enjoy their job and feel joy when to come to work. In a similar manner, the sense of community/team, has the second highest mean value is $4.80(S D=0.867)$. It indicates that respondents feel that, they are the part of the organization as a family. Likewise, the opinion statements on sense of community have a moderate agreement form the respondents. The respondents feel they are the part of a family in the organization, their team promotes creation of spirit of community, supports \& care each other, the respondents are linked with a common purpose. Likewise, sense of contribution to the community, has the mean value of 4.72 $(S D=0.944)$, which shows that the respondent agreed to their work is harmonious with their personal life values and is helpful for the community. The respondents agree work is connected with what they think is important in life, and they see a connection between their work and the larger social good of their community, and when working, they feel helpful for the whole society. Further, alignment between organizational and individual values, has the mean value of $4.45(S D=0.909)$, which indicate the slight agreement of their respondents towards the resemblance between organizational values and their individual value and their inner life. They slightly agree that they feel positive about the values prevailing in their organization, slightly feel good about their future with the organization, slightly agree on organization respects their "inner life", and slightly agree that organization helps them to live in peace/harmony.

However, the opportunities for the inner life has the mean value of 3.85 $(S D=1.433)$, the lowest of all dimensions of spirituality management. This indicates, the respondents are slightly disagreeing that the organization respects the spirituality and spiritual values of the individual.

\section{Status of employee productivity}

The result shows that, there is a moderate level $(m=4.68, S D=0.862$, in 6 point Likert scale, with 6 being 'strongly agree') of employee productivity in Nepalese hospitality organizations. The respondents slightly agree that everyone is busy in their workplace, the work quality is a high priority for them. Likewise, they agree that everyone gives their best efforts, the work group is very productive, very efficient in getting maximum, output from the resources the organization made available.

Table 2: Status of employee productivity

\begin{tabular}{|c|c|c|c|}
\hline Variables & Mean & $\begin{array}{c}\text { Std. } \\
\text { Deviation }\end{array}$ & Result \\
\hline Productivity & 4.68 & 0.862 & Agree \\
\hline
\end{tabular}




\section{Relationship of workplace spirituality and employee productivity}

Correlation analysis as presented in table 3 , indicates that there is a comparatively moderate correlation between workplace spirituality and productivity. Workplace spirituality has a positive relationship with productivity $(r=0.416, p=0.001)$. Correlation analyses results also shown that the dimensions of workplace spirituality also have weak to high relationship.

Likewise, employee productivity is positively related with the five dimensions of the workplace spirituality. Sense of meaningful work has a positive weak relationship $(r=0.394, p=0.001)$, sense of community/team has a positive strong relationship $(r=0.655, p=0.001)$, alignment between organizational and individual values has a positive moderate relationship; $(r=0.500, p=0.001)$, sense of contribution to the community has a positive weak relationship; $(r=0.245, p=0.003)$, with employee productivity at $1 \%$ level of significance level. Likewise, opportunities for the inner life has a positive weak relationship $(r=0.177, p=0.036)$ with employee productivity at $5 \%$ level of significance level.

Sense of community/team has the highest relationship with the productivity among the dimension of the workplace spirituality. It is followed by alignment between organizational and individual values, sense of meaningful work, sense of contribution to the community, and opportunities for the inner life.

Table 3: Relationship between workplace spirituality and productivity

\begin{tabular}{|c|l|r|r|r|r|r|r|}
\hline \multicolumn{2}{|c|}{ Variables } & \multicolumn{1}{c|}{ SMW } & \multicolumn{1}{c|}{ SC } & \multicolumn{1}{c|}{ AO } & \multicolumn{1}{c|}{ SCC } & \multicolumn{1}{c|}{ OIL } & \multicolumn{1}{c|}{ WPS } \\
\hline \multirow{2}{*}{ PRO } & $\mathrm{r}$ & 0.394 & 0.655 & 0.500 & 0.245 & 0.177 & 0.416 \\
\cline { 2 - 8 } & $\mathrm{p}$ & 0.001 & 0.001 & 0.001 & 0.003 & 0.036 & 0.001 \\
\hline
\end{tabular}

$P R O=$ Employee productivity; $S W M=$ Sense of meaningful work; $S C=$ Sense of community/team; $A O=$ Alignment between organizational and individual values; $S C C=$ Sense of contribution to the community; OIL= Opportunities for the inner life; WPS= Workplace spirituality

\section{Impact of workplace spirituality and employee productivity}

Further, multiple linear regression analysis is used to predict the impact of workplace spirituality dimensions to employee productivity. The regression analyses shown that the workplace spirituality dimensions positively predictive employee productivity $\left(R^{2}\right.$ $=0.507, p<0.01$ ). The results of regression analysis are summarized in Table 4 .

In the same fashion, there is a positive impact of the workplace spirituality dimensions to employee productivity is revealed by the regression analysis. The sense of meaningful work (SWM) $(\beta=.148, p<0.01)$, sense of community/team (SC) $(\beta=.634, p<0.01)$, alignment between organizational and individual values $(\mathrm{AO})(\beta=0.265, p<0.01)$, sense of contribution to the community (SCC) $(\beta=.406, p<0.01)$, has positive impact on employee 
productivity. Remarkably, the results revealed that opportunities for the inner life (OIL) $(\beta=0.002, p>0.05)$ has no statistically significant impact on employee productivity. The impact of sense of community/team is the highest among the dimension of workplace spirituality, followed by sense of contribution to the community.

Table 4: Impact of workplace spirituality and employee productivity

\begin{tabular}{|c|c|c|c|c|c|c|c|}
\hline Variables & $\mathbf{R}$ & $\mathbf{R}^{2}$ & F & p & b & $\mathbf{t}$ & p \\
\hline Constant & \multirow{6}{*}{0.712} & \multirow{6}{*}{0.507} & \multirow{6}{*}{27.778} & \multirow{6}{*}{0.001} & 1.636 & 5.010 & .000 \\
\hline $\mathrm{SWM} \rightarrow \mathrm{PRO}$ & & & & & .148 & 1.083 & .002 \\
\hline $\mathrm{SC} \rightarrow \mathrm{PRO}$ & & & & & .634 & 7.539 & .000 \\
\hline $\mathrm{AO} \rightarrow \mathrm{PRO}$ & & & & & .265 & 2.865 & .005 \\
\hline $\mathrm{SCC} \rightarrow \mathrm{PRO}$ & & & & & .406 & 3.627 & .000 \\
\hline $\mathrm{OIL} \rightarrow \mathrm{PRO}$ & & & & & .002 & .060 & .952 \\
\hline
\end{tabular}

\section{Hypotheses testing results}

$H_{1}$ : There is a positive impact of sense of meaningful work and employee productivity.

The regression analysis shows that there is an impact of sense of meaningful work on employee productivity $(r=0.148, t=1.083, p<0.01)$. Hence, $\mathrm{H}_{1}$ is accepted.

$\mathrm{H}_{2}$ : There is a positive impact of sense of community and employee productivity.

The regression analysis shows that there is an impact of sense of community on employee productivity $(r=0.634, t=7.539, p<0.01)$. Hence, $\mathrm{H}_{2}$ is accepted.

$\mathrm{H}_{3}$ : There is a positive impact of alignment between organizational and individual values and employee productivity.

The regression analysis shows that there is an impact of alignment between organizational and individual values on employee productivity $(r=0.0265, t=2.865$, $p<0.01)$. Hence, $\mathrm{H}_{3}$ is accepted.

$\mathrm{H}_{4}$ : There is a positive impact of sense of contribution to the community and employee productivity.

The regression analysis shows that there is an impact of sense of contribution to the community on employee productivity $(r=0.406, t=3.627, p<0.01)$. Hence, $\mathrm{H}_{4}$ is accepted.

\section{$\mathrm{H}_{5}$ : There is a positive impact of opportunities for the inner life and employee productivity.}

The regression analysis shows that there is an impact of opportunities for the inner life on employee productivity $(r=0.002, t=0.060, p>0.05)$. Hence, $\mathrm{H}_{5}$ is rejected. 


\section{Discussion}

This study focuses on the interface between workplace spirituality and employee productivity in Nepalese hospitality organizations. The result of this study suggests that, there is a moderate level of the workplace spirituality in Nepalese hospitality organizations. Rego and Cunha (2008) also found, exactly the same result, on average, individuals consider their workplace as being moderately spiritual, however, Rego and Cunha (2008) did not mentioned the type of organizations in their study.

In Nepalese hospitality organizations, employees perceived positively the meaningfulness of their work, they enjoy their job and feel joy when to come to work. Similarly, they feel that, they are the part of the organization as a family, they have team spirit, supports \& caring environment among them, and the employees are linked with a common purpose. Employees have their work harmonious with their personal life values. They have resemblance of organizational values, their individual value and their inner life. They feel slightly positive about the values prevailing in their organization and about their future with the organization. These findings support the thoughts on workplace spirituality by Ashmos and Duchon (2000), Smith and Rayment (2007), who stated that workplace spirituality is a state or experience that can provide individuals with direction or meaning, or provide feelings of understanding, support, inner wholeness or connectedness. However, the opportunities for the inner life has the lowest of all dimensions of spirituality management. This finding supports Rego and Cunha (2008) studies in which they found the lower scores to those measuring value alignment and opportunities for inner life. Equally important, there is a moderate level of employee productivity in Nepalese hospitality organizations, it is aligned with Fry (2003), who says that employees who have hope/faith in the organization's vision and who experience calling and membership will "Do what it takes" in pursuit of the vision to continuously improve and be more productive.

Some authors have recently called for empirical studies that can support anecdotal evidence and theoretical assumptions of a positive relationship between workplace (Rego and Cunha, 2008). In this endeavor, this study significantly contributes in the understating of the workplace and its relationship to employee productivity in hospitality organization. In this study, it is found that, there is a positive relationship between workplace spirituality and productivity. As a matter of fact, employee productivity is positively related with the five dimensions of the workplace spirituality. Sense of meaningful work, sense of community/team, alignment between organizational and individual values, sense of contribution to the community has a positive relationship with employee productivity at $1 \%$ level of significance level. Opportunities for the inner life has a positive relationship with employee productivity at $5 \%$ level of significance level. Sense of community/team has the highest relationship with the productivity among the dimension of the workplace 
spirituality. It supports the findings of Rego et al. (2007), Tevichapong (2009), Tevichapong et al. (2010), Amabile and Kramer (2011), these studies also found a significant relationship between workplace spirituality and self-reported individual performance. The results also support the previous studies by Garcia-Zamor (2003), Fairholm (1998), Fry (2003), Fry et al. (2005), Giacalone and Jurkiewicz (2003) and Millman et al. (2003), they also found that spirituality is associated with the positive work related attitudes, including productivity.

Finally, this study contributed to showing empirically how the employees' perceptions of workplace spirituality predict individual and organizational performance. This study suggests that the workplace spirituality dimensions positively predictive employee productivity. Sense of community/team is the major predictor of workplace spirituality among the dimensions, followed by sense of contribution to the community, alignment between organizational and individual values, and sense of meaningful work. The impact results of this study are congruent with theoretical and empirical evidence of the studies like Reave (2005), Fry (2003), Fry et. al., (2005), Malone and Fry (2003), Fry \& Slocum, 2008, Bodla \& Ali (2012), these studies stated that workplace spirituality lead to positive individual performance and also results in positive human health and psychological wellbeing, productivity. However, it was found that opportunities for the inner life has no statistically significant impact on employee productivity.

\section{Conclusion}

In conclusion, that there is a positive relationship between workplace spirituality and productivity and workplace spirituality positively predict employee productivity in hospitality organization. This suggests that the workplace spirituality plays an important role to make the employee productive and satisfied. In summary, if it is agreed that workplace spirituality has to do with the respect for employees' inner life, the search for meaningful work in the context of a community, the employees' sense of being connected to others in a way that provides feelings of completeness and joy, then our dimensions represent spiritual traits of the workplace climates (Rego and Cunha, 2008). Employee thus become more productive over the long run compared with employees in organizations where spirituality is ignored or disrespected.

Therefore, hospitality organizations should emphasize to make their respective organization spiritual and adopt spiritual environment, and also emphasize spiritual leadership. Consequently, if the organization neglect spirituality at work, it can greatly impact higher absenteeism and turnover, more neglecting behaviors and lower ability to satisfy customers, concretely results in lower performance at individual and organization level. A spiritually-rich workplace, may stimulate employees to form more positive perceptions of the organization and, thus, to appraise change more favourable and to achieve better adjustment through higher job satisfaction, 
psychological well-being, and organizational commitment, and lower absenteeism and turnover intentions (Martin et al., 2005).

\section{References}

Amabile, T., \& Kramer, S. (2011). The progress principle: Using small wins to ignite joy, engagement, and creativity at work. Harvard Business Press.

Arrindell, W. A., \& Van der Ende, J. (1985). An empirical test of the utility of the observations-to-variables ratio in factor and components analysis. Applied Psychological Measurement, 9(2), 165-178.

Ashmos, D. P., \& Duchon, D. (2000). Spirituality at work: A conceptualization and measure. Journal of management inquiry, 9(2), 134-145.

Bodla, M. A., \& Ali, H. (2012). Workplace spirituality: A spiritual audit of banking executives in Pakistan. African Journal of Business Management, 6(11), 3888.

Comrey, A. L., \& Lee, H. B. (1992). Interpretation and application of factor analytic results. Comrey AL, Lee HB. A first course in factor analysis, 2.

Dent, E. B., Higgins, M. E., \& Wharff, D. M. (2005). Spirituality and leadership: An empirical review of definitions, distinctions, and embedded assumptions. The leadership quarterly, 16(5), 625-653.

Duffy, R. D. (2006). Spirituality, religion, and career development: Current status and future directions. The Career Development Quarterly, 55(1), 52-63.

Ellison, L. (2006). A review of The Spiritual Well-Being Scale. NewsNotes, 44(1).

Ellison, L. L. (2006). The spiritual well-being scale.

Everitt, B. S. (1975). Multivariate analysis: The need for data, and other problems. The British Journal of Psychiatry, 126(3), 237-240.

Fairholm, G. W. (1998). Leadership as an exercise in virtual reality. Leadership \& Organization Development Journal, 19(4), 187-193.

Fry, L. W. (2003). Toward a theory of spiritual leadership. The leadership quarterly, 14(6), 693-727.

Fry, L. W. (2008). Spiritual leadership: State-of-the-art and future directions for theory, research, and practice. In Spirituality in business (pp. 106-124). Palgrave Macmillan, New York.

Fry, L. W., \& Matherly, L. L. (2006, August). Spiritual leadership and organizational performance: An exploratory study. In Annual Meeting of the Academy of Management,(11-16 A ğustos) Atlanta-Georgia. http://www. tarleton. edu/ fry/ sltorgperf. pdf Çă̆daş Liderlik Yaklaşımları. 
Fry, L. W., \& Slocum Jr, J. W. (2008). Maximizing the triple bottom line through spiritual leadership. Organizational dynamics, 37(1), 86-96.

Fry, L. W., Vitucci, S., \& Cedillo, M. (2005). Spiritual leadership and army transformation: Theory, measurement, and establishing a baseline. The leadership quarterly, 16(5), 835-862.

Garcia-Zamor, J. C. (2003). Workplace spirituality and organizational performance. Public administration review, 63(3), 355-363.

Garson, G. D. (2008). Structural Equations Modelling, from Statnotes: Topics in Multivariate Analysis. Retrieved on June, 15.

Giacalone, R. A., \& Jurkiewicz, C. L. (2003). Right from wrong: The influence of spirituality on perceptions of unethical business activities. Journal of Business Ethics, 46(1), 85-97.

Kunce, J. T., Cook, D. W., \& Miller, D. E. (1975). Random variables and correlational overkill. Educational and Psychological Measurement, 35(3), 529-534.

MacCallum, R. C., Widaman, K. F., Zhang, S., \& Hong, S. (1999). Sample size in factor analysis. Psychological methods, 4(1), 84.

Malone, P., \& Fry, L. W. (2003). Transforming schools through spiritual leadership: A field experiment. In Annual Meeting of the Academy of Management,(1-6 Ağustos). Seattle-Washington.

Marascuilo, L. A., \& Levin, J. R. (1983). Multivariate statistics in the social sciences: A researcher's guide. Wadsworth Publishing Company.

Martin, A. J., Jones, E. S., \& Callan, V. J. (2005). The role of psychological climate in facilitating employee adjustment during organizational change. European Journal of Work and Organizational Psychology, 14(3), 263-289.

Milliman, J., Czaplewski, A. J., \& Ferguson, J. (2003). Workplace spirituality and employee work attitudes. Journal of Organizational Change Management, 16(4), 426.

Mitroff, I. I., \& Denton, E. A. (1999). A study of spirituality in the workplace. MIT Sloan Management Review, 40(4), 83.

Mohd Yusof, J., \& Mahadzirah, M. (2014). The relationship between spiritualleadership, spiritual well-being and job satisfaction in the Malaysian shipping industry: A pilot study. International Journal of Research In Social Sciences, 4(8), 1-13.

Nunnally, J. C., \& Bernstein, I. H. (1978). Psychometric theory.

Nyhan, R. C. (2000). Changing the paradigm: Trust and its role in public sector organizations. The American Review of Public Administration, 30(1), 87-109. 
Paloutzian, R. F., \& Ellison, C. W. (1982). Loneliness, spiritual well-being and the quality of life. Loneliness: A sourcebook of current theory, research and therapy, 224-237.

Podsakoff, P. M., MacKenzie, S. B., Lee, J. Y., \& Podsakoff, N. P. (2003). Common method biases in behavioral research: A critical review of the literature and recommended remedies. Journal of applied psychology, 88(5), 879.Reave, 2005)

Rego, A., \& Pina e Cunha, M. (2008). Workplace spirituality and organizational commitment: an empirical study. Journal of organizational change management, 21(1), 53-75.

Rego, A., Pina E. Cunha, M., \& Souto, S. (2007). Workplace spirituality, commitment, and self-reported individual performance: An empirical study. Management Research: Journal of the Iberoamerican Academy of Management, 5(3), 163-183.

Salehzadeh, R., Khazaei Pool, J., Kia Lashaki, J., Dolati, H., \& Balouei Jamkhaneh, H. (2015). Studying the effect of spiritual leadership on organizational performance: an empirical study in hotel industry. International journal of culture, tourism and hospitality Research, 9(3), 346-359.

Smith, J. A., \& Rayment, J. J. (2007). The global SMP fitness framework: A guide for leaders exploring the relevance of spirituality in the workplace. Management Decision, 45(2), 217-234.

Tevichapong, P. (2009, August). The relationships between spirit at work and employee work attitudes and organizational outcomes. In Best Paper Proceedings of the Sixty-eighth Annual Meeting of the Academy of Management. Chicago, IL.

Tevichapong, P., Davis, A., \& Guillaume, Y. (2010). Individual spirit at work and its outcomes: An empirical examination in corporate Thailand.

Velicer, W. F., \& Fava, J. L. (1998). Affects of variable and subject sampling on factor pattern recovery. Psychological methods, 3(2), 231.

World travel \& tourism council (wttc). (2017). Travel \& tourism economic impact 2017 world. Available at www.wttc.org. Downloaded on $20^{\text {th }}$ January 2018.

Wrzesniewski, A., LoBuglio, N., Dutton, J. E., \& Berg, J. M. (2013). Job crafting and cultivating positive meaning and identity in work. In Advances in positive organizational psychology (pp. 281-302). Emerald Group Publishing Limited.

Zanganeh, M., \& Malekmohammadi, M. (2015). The Relationship between Organizational Learning and Spiritual Leadership with Empowering Employees of Bank Keshavarzi of Golestan Province.

Zellers, K. L., \& Perrewe, P. L. (2003). In RA Giacalone, \& CL Jurkiewicz. Handbook of workplace spirituality and organizational performance, 300-313. 